Acta vet. scand. $1967,8,195-200$.

From the Department of Microbiology and Epizootiology,

College of Veterinary Medicine, Helsinki, Finland.

\title{
THE COLICINOGENIC PROPERTIES OF PORCINE ESCHERICHIA COLI STRAINS
}

\author{
By \\ Helvi Vasenius
}

Colicines are substances produced by certain genera of the family Enterobacteriaceae with the ability to inhibit the growth of the same or related bacterial species. By nature the colicines are macromolecular proteins or polypeptides of which for the present at least 17 different types are known (Fredericq 1957, 1965). The ability to produce colicine is a stable hereditary property. Bacteria forming colicine are called colicinogenic and the genetic determinants of colicinogenicity are known as colicinogenic factors. By nature the colicinogenic factors are episomes, functioning independently of the chromosomal structure of the bacteria and thus in a high degree resembling the genetic material of temperate bacteriophages (Jacob \& Wollman 1961). As a rule the colicinogenic factors transfer very easily between bacteria and at least regarding some types of colicine the frequency of transfer in the case of strains just infected is considerably higher than in strains where the colicinogenic factor has been more permanent (Smith et al. 1963, Kahn \& Helinski 1964, Monk \& Clowes 1964).

Thus far the colicinogenic properties of the enteric bacteria of animals have not been much investigated. Papavassiliou (1963) investigated the colicine production of Escherichia coli strains in the normal intestinal flora in man, sheep and hen and did not find any considerable differences in the number of the colicinogenic bacteria between these species. Thus far no compre- 
hensive investigations have been made in regard of the occurrence of colicinogenic E. coli strains in pigs.

The present writer investigated the colicine production of E. coli strains isolated in healthy pigs and in pigs affected with colibacillosis paying particular attention of the colicine production at different incubation temperatures.

\section{MATERIAL AND METHOD}

The field material comprises altogether 789 E. coli strains of which 435 were isolated in cases of colibacillosis (one strain per case) and 354 strains in 101 healthy pigs.

All colicine tests were made by incubating the strains as simultaneous cultures for $48 \mathrm{hrs}$. at $37^{\circ} \mathrm{C}$ and $40^{\circ} \mathrm{C}$ respectively. The procedure adopted was in broad outlines similar to that described by Fredericq (1958). A sensitive indicator strain isolated in intestinal content from a healthy pig was used in each test (Vasenius 1966). The diameter of the inhibitory zone produced by the colicinogenic strains was measured. Note was also made of the clarity of demarcation of the zone. In the case of a poorly distinguished belt its extent was measured from the middle of the diffuse area.

\section{RESULTS}

It was found that of the $435 \mathrm{E}$. coli strains isolated in colibacillosis cases 258 produced colicine, whereas only 61 of the 354 strains from healthy pigs possessed this property. Of the 258 colicinogenic strains of the first mentioned group 16 produced colicine at $40^{\circ} \mathrm{C}$ only, 2 at $37^{\circ} \mathrm{C}$ but not at $40^{\circ} \mathrm{C}$, and in 12 cases the inhibition zone was not measurable because of its diffuse demarcation and/or the secondary growth on the inhibitory area.

The results of the colicine production at different incubation temperatures of the 435 enteropathogenic strains in the five serotypes commonly occurring in Finland (Schulman et al. 1965) are presented in Table 1.

The table reveals that the inhibitory zone of the colicinogenic E. coli strains incubated at $40^{\circ} \mathrm{C}$ is considerably wider than that of the same strains incubated at $37^{\circ} \mathrm{C}$. The difference is statistically significant. It may be mentioned that although as a rule no particular clear differences were observed in the form and sharpness of the edges of the inhibitory zones at different incubation 
Table 1. Colicine production of 435 enteropathogenic porcine E. coli strains.

\begin{tabular}{|c|c|c|c|c|c|c|c|}
\hline \multirow{3}{*}{$\begin{array}{l}\text { Serological } \\
\text { group }\end{array}$} & \multirow{2}{*}{\multicolumn{2}{|c|}{ Colicinogenic strains }} & \multicolumn{2}{|c|}{ Inhibition zone, $\mathrm{mm}$} & \multirow{3}{*}{$\begin{array}{c}\text { Correlation } \\
\text { coefficient }\end{array}$} & \multirow{2}{*}{\multicolumn{2}{|c|}{$\begin{array}{l}\text { Regression } \\
\text { coefficient }\end{array}$}} \\
\hline & & & \multirow{2}{*}{$\frac{37^{\circ} \mathrm{C}}{\text { mean } \pm \mathrm{s}}$} & \multirow{2}{*}{$\frac{40^{\circ} \mathrm{C}}{\text { mean } \pm \mathrm{s}}$} & & & \\
\hline & per cent & number & & & & $\mathrm{b}_{\mathbf{4}} 0^{\circ} / \mathbf{3 7 ^ { \circ }}$ & $\mathbf{b}_{37^{\circ}} / 40^{\circ}$ \\
\hline 08 & 45 & 43 & $10.3 \pm 2.2$ & $12.5 \pm 2.5$ & 0.83 & 0.93 & 0.73 \\
\hline 0138 & 42 & 18 & $9.3 \pm 2.1$ & $12.2 \pm 2.2$ & 0.56 & 0.58 & 0.54 \\
\hline 0139 & 35 & 8 & $9.8 \pm 0.9$ & $13.3 \pm 1.8$ & 0.60 & 1.18 & 0.30 \\
\hline $0141 a b$ & 58 & 44 & $11.7 \pm 2.8$ & $14.7 \pm 2.8$ & 0.74 & 0.75 & 0.74 \\
\hline O141ac & 70 & 31 & $12.9 \pm 4.4$ & $16.5 \pm 4.5$ & 0.79 & 0.82 & 0.76 \\
\hline Other types & 55 & 84 & $10.3 \pm 2.9$ & $12.7 \pm 3.2$ & 0.92 & 1.01 & 0.83 \\
\hline Total & 52.4 & 228 & $10.8 \pm 3.1$ & $13.5 \pm 3.4$ & 0.84 & 0.93 & 0.76 \\
\hline
\end{tabular}

temperatures the demarcation of the zones was in general sharper at $40^{\circ} \mathrm{C}$ than at $37^{\circ} \mathrm{C}$. Statistically significant differences were noticed in both incubation temperatures used in the extent of the inhibitory zone between the strains in 0141 group and the other strains, as well as between both subtypes in the group 0141, the $t$-values ranging from 2,129 to 5,7008 for 226 degrees of freedom.

Table 2 presents the results of colicine production of the 354 E. coli strains isolated in healthy pigs.

It may be noticed that among the five serological groups colicinogenic strains occurred almost solely in the 0138 group.

T a b l e 2. Colicine production of 354 E. coli strains isolated in 101 healthy pigs.

\begin{tabular}{|c|c|c|c|c|c|}
\hline \multirow{3}{*}{$\begin{array}{l}\text { Serological } \\
\text { group }\end{array}$} & \multirow{3}{*}{$\begin{array}{l}\text { Number of } \\
\text { strains }\end{array}$} & \multirow{2}{*}{\multicolumn{2}{|c|}{ Colicinogenic strains }} & \multicolumn{2}{|c|}{ Inhibition zone, $\mathrm{mm}$} \\
\hline & & & & \multirow{2}{*}{$\frac{37^{\circ} \mathrm{C}}{\text { mean } \pm \mathrm{s}}$} & \multirow{2}{*}{$\frac{40^{\circ} \mathrm{C}}{\text { mean } \pm \mathrm{s}}$} \\
\hline & & 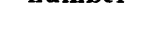 & & & \\
\hline 08 & 12 & 0 & - & & \\
\hline 0138 & 38 & 20 & 53 & $10.8 \pm 1.9$ & $14.5 \pm 2.8$ \\
\hline 0139 & 18 & 0 & - & & \\
\hline $0141 \mathrm{ab}$ & 1 & 0 & - & & \\
\hline $0141 \mathrm{ac}$ & 5 & $\left.2^{\star}\right)$ & (40) & $10.0-$ & $?$ \\
\hline Other types & 280 & 39 & 14 & $13.9 \pm 4.0$ & $17.0 \pm 4.4$ \\
\hline Total & 354 & 61 & 17 & $13.1 \pm 3.4$ & $16.1 \pm 3.9$ \\
\hline
\end{tabular}

*) Colicine production doubtful at $40^{\circ} \mathrm{C}$. 


\section{DISCUSSION}

Many investigators are of the opinion that the production of colicine is of certain importance in the maintenance of the equilibrium of the intestinal flora. It has been noted that the greater the frequency of colicinogenic strains in the intestinal flora of a particular individual, the stabler is the flora (Branche et al. 1960, Mushin \& Dubos 1966). In the present study it was found that the normal $E$. coli flora in pigs contained relatively few colicinogenic strains. On the other hand the E. coli flora of the pigs is notoriously relatively labile, and especially during the weaning period or in connection with a sudden change in the diet it is known that certain, mostly haemolytic E. coli strains increase in abnormally large numbers in the intestine causing disturbances in the host animal.

Strains isolated in cases of colibacillosis were found in vitro to be mostly colicinogenic. It is, however, very difficult to assess what significance can be ascribed to the colicine formation in the sudden increase of the pathogenic E. coli strains, but it would seem evident that the ability to produce colicine would be at least a contributory factor in the preservation of potentially pathogenic strains among the intestinal flora of healthy pigs.

The colicine production of the porcine $\mathrm{E}$. coli strains in vitro is obviously more intensive at $40^{\circ} \mathrm{C}$ than at $37^{\circ} \mathrm{C}$ which seems quite natural considering the relatively high body temperature of the pig. According to the present writers' view this higher incubation temperature is preferable in determination of the colicinogenic capacities of porcine E. coli strains.

\section{REFERENCES}

Branche, W. C. Jr., V.M. Young, H. Gillem \& E. D. Massey: Observations on Escherichia coli as a component of the normal intestinal flora; effect of colicine production. Bact. Proc. 1960, 134.

Fredericq, P.: Colicins. Ann. Rev. Microbiol. 1957, 11, 7-22.

Fredericq, P.: Colicins and colicinogenic factors. Synı. Soc. exp. Biol. 1958, 104-122.

Fredericq, P.: Genetics of colicinogenic factors. Zbl. Bakt., I. Abt. Orig. 1965, 196, 142-151.

Jacob, F. \& E. Wollman: Sexuality and the genetics of bacteria. Academic Press, New York and London 1961.

Kahn, P. L. \& D. Helinski: Studies on the relationship between colicinogenic and $F$ factors. Bact. Proc. 1964, 31. 
Monk, M. \& R. C. Clowes: The regulation of colicin synthesis and colicin factor transfer in Escherichia coli K12. J. gen. Microbiol. $1964,36,385-392$.

Mushin, R. \& R. Dubos: Coliform bacteria in the intestine of mice. J. exp. Med. 1966, 123, 657-663.

Papavassiliou, J.: Colicinogenic enterobacteria in human and animal faeces. Z. Hyg. Infekt.-Kr. 1963, 149, 164-169.

Schulman, A., H. Vasenius \& H. Stenberg: The occurrence of haemolytic Escherichia coli in Finnish pigs. Nord. Vet.-Med. 1965, 17, $22-30$.

Smith, S. M., H. Ozeki \& B. A. D. Stocker: Transfer of Col E1 and Col E2 during high frequency transmission of Col I in Salmonella typhimurium. J. gen. Microbiol. 1963, 33, 231-242.

Vasenius, H.: Factors influencing the rapid multiplication of enteropathogenic porcine Escherichia coli strains. Thesis. Helsinki 1966.

\section{SUMMARY}

The colicine production of 789 porcine E. coli strains was investigated in temperatures of $37^{\circ} \mathrm{C}$ and $40^{\circ} \mathrm{C}$ respectively. The results are expressed in tabular form. It was found that of 435 strains isolated from an equal number of colibacillosis cases about $60 \%$ were colicinogenic, $52.4 \%$ producing colicine in both incubation temperatures used, whereas of 354 strains isolated in the intestinal content of healthy pigs only $17 \%$ produced colicine. The inhibitive zone formed by strains belonging to $O$-groups $141 \mathrm{ab}$ and $141 \mathrm{ac}$ was significantly larger than that formed by other serological groups. It was found that in nearly all colicinogenic strains the inhibitive zone was larger when incubated at $40^{\circ} \mathrm{C}$ than at $37^{\circ} \mathrm{C}$. The higher incubation temperature is recommended in determination of colicine production of porcine E. coli strains.

\section{ZUSAMMENFASSUNG}

Die kolizinogenen Eigenschaften aus Ferkeln isolierter Escherichia coli-Stämme.

Die Kolizinbildungsfähigkeit von 789 aus Ferkeln isolierten E. coliStämmen wurde bei Temperaturen von $37^{\circ} \mathrm{C}$ resp. $40^{\circ} \mathrm{C}$ untersucht. Die quantitativen Resultate sind in zwei Tabellen dargestellt. Von 435 Stämmen, die aus derselben Zahl an Kolibazillose erkrankten Ferkeln isoliert wurden, erzeugte 52,4\% Kolizin in beiden Inkubationstemperaturen; insgesamt etwa $60 \%$ wurden als kolizinogen betrachtet, während von 354 aus dem Darm gesunder Ferkel isolierten Stämmen nur etwa $17 \%$ Kolizin erzeugte. Escherichiastämme der O-Gruppe $141 \mathrm{ab}$ und 141ac bildeten deutlich breitere Inhibitionszonen als Stämme anderer serologischen Gruppen. In fast sämtlichen Fällen war die Kolizinproduktion grösser bei $40^{\circ} \mathrm{C}$ als bei $37^{\circ} \mathrm{C}$, weshalb die höhere Inkubationstemperatur bei der Arbeit mit aus Ferkeln isolierten E. coli-Stämmen zu empfehlen ist. 


\section{SAMMANFATTNING}

Colicinogena egenskaper hos från svin isolerade E. coli-stammar.

Sammanlagt 789 E. coli-stammar, vilka isolerats från grisar, undersöktes beträffande förmågan att bilda colicin vid $37^{\circ} \mathrm{C}$ resp. $40^{\circ} \mathrm{C}$. De kvantitativa resultaten är givna i två tabeller. Av 435 stammar, vilka isolerats från fall av colibacillos, bildade $52,4 \%$ colicin vid bägge inkubationstemperaturerna och sammanlagt c:a $60 \%$ betraktades såsom colicinogena, medan av 354 stammar från friska grisar endast c:a $17 \%$ bildade colicin. Stammar av O-grupperna 141ab och 141ac bildade signifikant bredare inhibitionszoner än stammar tillhörande andra serogrupper. I nästan samtliga fall var colicinproduktionen mera betydande vid $40^{\circ} \mathrm{C}$ än vid $37^{\circ} \mathrm{C}$, varför den högre inkubationstemperaturen är att rekommendera vid arbete med E. coli-stammar vilka isolerats från grisar.

(Received January 2, 1967). 